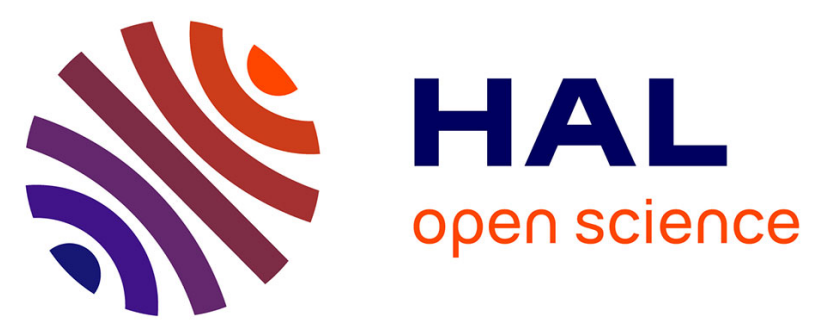

\title{
The diatom Thalassiosira faurii (Gasse) Hasle in the Ziway-Shala lakes (Ethiopia) and implications for paleoclimatic reconstructions: Case study of the Glacial-Holocene transition in East Africa
}

Vincent Roubeix, Françoise Chalié, Françoise Gasse

\section{To cite this version:}

Vincent Roubeix, Françoise Chalié, Françoise Gasse. The diatom Thalassiosira faurii (Gasse) Hasle in the Ziway-Shala lakes (Ethiopia) and implications for paleoclimatic reconstructions: Case study of the Glacial-Holocene transition in East Africa. Palaeogeography, Palaeoclimatology, Palaeoecology, 2014, 402, pp.104 - 112. 10.1016/j.palaeo.2014.03.014 . hal-01479319

\author{
HAL Id: hal-01479319 \\ https://hal.science/hal-01479319
}

Submitted on 28 Feb 2017

HAL is a multi-disciplinary open access archive for the deposit and dissemination of scientific research documents, whether they are published or not. The documents may come from teaching and research institutions in France or abroad, or from public or private research centers.
L'archive ouverte pluridisciplinaire HAL, est destinée au dépôt et à la diffusion de documents scientifiques de niveau recherche, publiés ou non, émanant des établissements d'enseignement et de recherche français ou étrangers, des laboratoires publics ou privés. 


\title{
The diatom Thalassiosira faurii (Gasse) Hasle in the Ziway-Shala lakes
}

\author{
Vincent Roubeix ${ }^{1}$, Françoise Chalié, Françoise Gasse
}

Aix-Marseille Université, CNRS-UMR 7330, CEREGE UM34, Europôle Méditerranéen de l'Arbois - BP 80 13545 Aix-en-Provence, France.

Abstract: The species Thalassiosira faurii (Gasse) Hasle was found dominating the planktonic diatom community during summer 2012 in lake Langano which is part of the Ziway-Shalla alkaline lake system in

11 Ethiopia. In a previous study, the species had been recorded in high abundance in 13-12 cal. ka old sediments from the neighbour lake Abiyata. Using a transfer function for conductivity, peaks in abundance had been interpreted as dry spells at the Pleistocene-Holocene transition since the species was considered strictly halophilous.

In this study, a strain of $T$. faurii was isolated from lake Langano and grown in the laboratory. The observation of its morphology and reproduction, and comparison between modern and fossil populations helped to improve the taxonomic definition of the species. The autecology of the species was also investigated through a salinity tolerance test. The results revealed that the species was much more sensitive to salinity than previously admitted. A new conductivity optimum was derived from the experiment and incorporated into the transfer function. The reassessment of lake conductivity variations along the core of lake Abiyata showed that the intensity of the dry periods preceding the onset of the Holocene had been probably over-estimated. The reconsideration of the species relationship to conductivity may have important consequences on paleoclimatic reconstructions in tropical Africa where T. faurii has been reported in abundance. The use of experimentation on local diatom strains allows paleoecologists to solve the problems of low representation of some species in modern data set and of regional autecological variability within morphotypes.

${ }^{1}$ Corresponding author and present address: Irstea, UR HYAX, Pôle Onema-Irstea Hydroécologie plans d'eau, 3275 route Cézanne,CS 40061, 13182 Aix-en-Provence Cedex 5 


\section{1- Introduction}

41 Diatoms are well-known bioindicators of water quality and their resistant frustules are used to reconstruct paleolimnological conditions from lake sediments. This requires a precise knowledge of species ecological preferences which can be obtained from the modern repartition of living species across environmental gradients, assuming that species autecological characteristics have not evolved at the time scale considered. Diatoms are particularly sensitive to salinity (or conductivity) (Snoeijs and Weckström, 2010), which mostly results in closed lakes from a modification of the precipitation-evaporation (P-E) balance. Thus they can be used as indirect indicators of climate change (Gasse et al., 1997). An extended modern African database has been compiled by including samples from Northwest and East Africa and from Niger, and representing a large range of conductivity (Gasse et al., 1995). From this database, a transfer function has been developed based on two way weighted averaging (Birks et al., 2010) in order to infer past lake water conductivity from sediment diatom assemblages (Gasse et al., 1995).

The transfer function has been used for many paleo-climatic reconstructions in Africa (e.g. Barker et al., 2002; Ryner et al., 2007; Fritz et al., 2010). It was notably applied to a Late glacial-Holocene sedimentary sequence from the Ziway-Shala lake system, an endorheic chain of four lakes located in the Ethiopian rift valley at altitudes ranging from of 1636 to $1557 \mathrm{~m}$ a.s.l (Fig. 1, Legesse et al., 2002). The lakes are alkaline of the sodium-carbonate type and present an altitudinal salinity and $\mathrm{pH}$ gradient from freshwater conditions in the highest lake Ziway $\left(600 \mu \mathrm{S} . \mathrm{cm}^{-1}, \mathrm{pH}=8\right)$ to hyper-alkaline waters in the lowest lake Shala $(>20,000$ $\left.\mu S . \mathrm{cm}^{-1}, \mathrm{pH}=10\right)($ Kebede et al., 1994, Legesse and Ayenew, 2006). In the middle of the system, lake Langano has a closed drainage basin $\left(1600 \mathrm{~km}^{2}\right)$, a surface of $241 \mathrm{~km}^{2}$ and a mean depth of $17 \mathrm{~m}$ (max 47 m). It discharges via the temporary river Hora Kelo into the neighbour terminal lake Abiyata, from which a core was extracted in 1995 and analysed (Chalié and Gasse, 2002).

Diatom analysis in sediments revealed a long period of low conductivity during the Early Holocene, when the four lakes formed a single open freshwater lake, followed by a sharp increase at about 5.5 cal ka BP which marked the end of the African Humid period (Gasse, 2001). However, large uncertainty remained in the interpretation of the fossil record when a diatom species reached high relative abundance in the fossil assemblages whereas its conductivity optimum was not well defined because of a poor representation of the taxon in the modern training set. The species Thalassiosira faurii (Gasse) Hasle was identified as such a problematic species since it occurred in a limited number of samples in the African data set, and it dominated the assemblage in a few sediment samples (Chalié and Gasse, 2002).

T. faurii is a centric planktonic diatom which was first described by Gasse (1975) from sediment samples 
collected in lakes of Central Afar (Djibouti). According to Gasse (1986), this species was associated with hyperalkaline environments at conductivities over $5000 \mu \mathrm{S} . \mathrm{cm}^{-1}$. However, T. faurii was recently found to dominate the diatom planktonic community in Lake Langano whose conductivity is lower than $2000 \mu \mathrm{S} . \mathrm{cm}^{-1}$.

74 Then, in order to better characterize the autecology of the species, a strain was isolated from lake water and maintained in laboratory for observations and experimentation.

The objectives of this study were (1) to assess the current abundance of T. faurii in lake Langano (2) to investigate the taxonomic definition of the species, (3) to determine experimentally its tolerance to salinity, and (4) consequently, to revisit the hydrological and climatic interpretations made from the sediments where T. faurii was abundant.

\section{2- Material and Methods}

\subsection{Diatom observation}

A sediment trap was used to collect planktonic diatoms in lake Langano during summer 2012. It was made using a plastic pipe $(12.5 \mathrm{~cm}$ diameter $\times 80 \mathrm{~cm}$ length $)$, anchored at the bottom and maintained straight in the water column by two lateral buoys. It was placed on the west shore of the lake at 4 meters below the surface and $1 \mathrm{~m}$ above the bottom. Samples were taken monthly in July, August and September in association with physico-chemical measurements of surface water (temperature, $\mathrm{pH}$, conductivity). Each time, diatoms were collected after settling of the trap content in a $15 \mathrm{~L}$ flask during $48 \mathrm{~h}$ in the dark. Diatoms were extracted from sediment samples by oxidizing organic matter and dissolving carbonates in boiling $\mathrm{H}_{2} \mathrm{O}_{2}$ and $\mathrm{HCl}$ solutions respectively, and mounted in naphrax for examination in light microscopy (LM). At least 400 valves were counted and species were identified using African and European taxonomic references (Hustedt, 1949; Gasse, 1986; Cocquyt, 1998; Krammer and Lange-Bertalot, 1986, 1988, 1991a,b). The density of areolae was estimated on circles concentric with the valve. A monoclonal strain of Thalassiosira faurii was isolated by micromanipulation from a water sample taken in lake Langano in June 2012 and kept in the fridge until return to the laboratory. It was maintained at room temperature and at day light in a culture medium made of $0.2 \mu \mathrm{m}$-filtrated lake water $\left(1750 \mu \mathrm{S} . \mathrm{cm}^{-1}\right)$, enriched with the nutrient basis of the WC medium (Guillard and Lorenzen, 1972) and autoclaved. Vegetative and sexual reproduction of the species was observed at inverted microscope. The fine structure of the frustules produced along the life cycle was examined under a Leica microscope (x1000 magnification) and coupled digital camera, and with a scanning electronic microscope (SEM, type XL 30 ESEM Philips). A monoclonal F1 population was used to test species tolerance to salinity.

101 In order to compare with another typical species in hyper-alkaline lakes, a strain of the benthic species 
Anomoeoneis sphaerophora was also isolated at the same time from an epiphyton sample of lake Langano.

103 A large-cell monoclonal culture was obtained after sexual reproduction. Its tolerance to salinity was tested in 104 the same conditions but only at the two extremes of the salinity range used for T. faurii.

\subsection{Tests of tolerance to salinity}

106 The tolerance of $T$. faurii to salinity was assessed from the variations of its growth rate in batch cultures at 107 different salinities. The range of tested salinities was obtained as following: (1) partial evaporation of lake 108 water at $80^{\circ} \mathrm{C}$ (up to $10,300 \mu \mathrm{S} . \mathrm{cm}^{-1}$ ), (2) dilution at different levels with deionized water, (3) enrichment with 109 nutrients of the WC culture medium and (4) autoclave. A growing culture of $T$. faurii was inoculated at $2 \%$ into 11018 sterile transparent plastic flasks $(30 \mathrm{~mL})$ representing 6 salinities in triplicates $(158,424,945,2050,4357$ 111 and $\left.9110 \mu \mathrm{S} . \mathrm{cm}^{-1}\right)$. The flasks were placed on a rotating panel at an illumination of $400 \mu \mathrm{mol} \cdot \mathrm{m}^{-2} \cdot \mathrm{s}^{-1}$ with a 112 14:10 light/dark cycle. Temperature was kept constant at $23^{\circ} \mathrm{C}$. Diatom cells were counted daily at inverted 113 microscope during 15 days. Growth rate was determined as the slope of the curve representing the evolution

114 of diatom abundance (in log) during the exponential growth phase. Conductivity and pH were measured at 115 the end of the experiment in each culture using a pH-conductimeter (WTW 340i).

\subsection{Paleolimnological reconstructions}

117 The conductivity optimum of $T$. faurii, formerly derived from its abundance in sites of a modern training set, 118 was re-estimated from test results as an average log-transformed conductivity weighted by growth rates. The 119 empiric optimum of the species was simply replaced by the new experimental one in the transfer function for 120 conductivity (Gasse et al., 1995) to gain local relevance. The modified transfer function was applied to the

121 sedimentary sequence of Lake Abiyata (Chalié and Gasse, 2002) leading to reconsider the previous 122 paleolimnological reconstructions and paleoclimatic interpretations.

\section{3- Results}

\section{$124 \quad 3.1 \quad T$. faurii in lake Langano}

125 During the months of July, August and September, more than half of the planktonic diatoms belong to the 126 species T. faurii (Fig. 2) exhibiting a large dominance in the community. The second most abundant species 127 did not exceed $10 \%$ of diatom cells. Among the subdominant species, there were the benthic Rhopalodia 128 gibberula and Encyonema muellerii, some Nitzschia species and rare planktonic taxa (Aulacoseira sp.) and 129 facultative planktonic taxa (Pseudostaurosira brevistriata, Cyclotella ocellata). Lake water conductivity and $130 \mathrm{pH}$ measurements were in between 1200 and $1770 \mu \mathrm{S} . \mathrm{cm}^{-1}$, and 8.34 and 9.18 respectively. Water 131 temperature was $22-23^{\circ} \mathrm{C}$ and the high turbidity resulted in a Secchi depth of about $20 \mathrm{~cm}$. 


\subsection{Species description}

133 The isolate from lake Langano grew well in laboratory conditions. Most of the cells were solitary or 134 associated in short chains of up to four cells. Organic threads were visible in LM either prolongating the 135 marginal fultoportulae or connecting the cells in chains. In natural populations collected in the sediment 136 traps, frustules appeared rectangular in girdle view with a flat valve face (Fig. 3).Valve diameter ranged 137 between 17 and $47 \mu \mathrm{m}$. There were about 14-17 areolae in $10 \mu \mathrm{m}$ with circular to oval foramina and internal 138 cribra (Fig. 3 and 4). The density of areolae on the mantle was estimated at SEM to be 20 in $10 \mu \mathrm{m}$.

139 Fultoportulae had very short internal tubes surrounded by 4 satellite pores. The central fultoportulae 140 appeared at mid-distance between valve center and margin, they were either isolated or arranged in groups 141 of two or three (Fig. 5). Their observed number varied from two on the smallest valves up to eight forming a 142 circle around the center of the valve. There were differences between individuals of the same clone and 143 between valves of the same individual, as observed on undissociated frustules in LM. Marginal fultoportulae 144 were arranged regularly in a single ring near the valve margin (4-7 in $10 \mu \mathrm{m})$ with 2-3 areolae between two adjacent processes. They opened externally through straight tubes (1-2 $\mu \mathrm{m}$ long) whose directions had a radial and a pervalvar component, making a constant angle with the valve radius (Fig. 3). The maximal number of rimoportulae observed on one valve was five. They were located between two marginal fultoportulae, often closer to one of them and their labiate internal opening was radially orientated. The external tubes of the rimoportulae were similar to those of the marginal fultoportulae but their direction was deviated towards the pervalvar axis. Generally, the number and distribution of central fultoportulae and

152 Oogamous sexual reproduction occurred when light conditions for the culture were modified. Some cells 153 produced uniflagellate spermatozoids whereas others differentiated into oogonia (Fig. 6). Spermatozoids 154 were often found fixed at the surface of oogonia, suggesting that fertilization took place. Spheric auxospores 155 developed between the valves of the oogonia. The mature auxospore was split up into two equal parts and 156 the initial cell was produced from the basis of each hemisphere. The onset of auxosporulation allowed a 157 better estimation of the minimal and maximal sizes of the species: valve diameter was $15-20 \mu \mathrm{m}$ for mother 158 cells and $45-50 \mu \mathrm{m}$ for initial cells.

\section{$159 \quad 3.3$ Tolerance to salinity}

160 The growth rate of T. faurii was optimal at the two lowest salinities tested (about $0.8 \mathrm{~d}^{-1}$, Fig. 7). It was slightly 161 reduced at about $1000 \mu \mathrm{S} . \mathrm{cm}^{-1}$ and no net growth was observed at 2,000 $\mu \mathrm{S} . \mathrm{cm}^{-1}$ although cells were still 162 alive. From $4,000 \mu \mathrm{S} . \mathrm{cm}^{-1}$ onwards, all cells died rapidly. The application of the weighted average method 
using growth rates resulted in a conductivity optimum of $2.6\left(400 \mu \mathrm{S} . \mathrm{cm}^{-1}\right)$. There was an increase of $\mathrm{pH}$

164 from 8.2 to 9.6 as lake salts were gradually concentrated. The species $A$. sphaerophora showed an opposite 165 response with salinity: its net growth rate was null at the lower salinity tested $\left(251 \mu \mathrm{S} . \mathrm{cm}^{-1}\right.$, cells alive), and it 166 reached $0.22 \mathrm{~d}^{-1}$ at $8,060 \mu \mathrm{S} . \mathrm{cm}^{-1}$.

\section{$167 \quad 3.4$ Paleo-conductivity reassessment in lake Abiyata}

168 In the sediment core from lake Abiyata, T. faurii appeared in abundance only between 12 and 13.5 cal ka BP 169 (Fig. 8). Its relative abundance peaked over $60 \%$ at 12.5 and $13.5 \mathrm{cal}$ ka BP. These high values had been 170 interpreted as two peaks of conductivity in the lake, indicating a drier climate. Including the 'experimental' 171 optimum of $T$. faurii in the transfer function resulted in a much lower conductivity when $T$. faurii was 172 abundant. Diatom-inferred conductivity was reduced to about the same values as during the Early Holocene 173 (12 to 5.7 cal ka BP), and the signs of an abrupt climate change around $12 \mathrm{cal}$ ka BP disappeared.

174 The composition of two consecutive fossil assemblages are detailed in Fig. 9, at approximately 12.5 and 12.3 175 cal ka BP, when the relative abundance of $T$. faurii was 72 and $51 \%$ respectively. The species associated with $T$. faurii at 12.5 cal ka BP were mostly benthic and the assemblage was characterized by a wide distribution of specific optima for conductivity. Indeed, among the most abundant species after T. faurii, there were diatoms representative of high (Rhopalodia gibberula, Anomoeoneis sphaerophora var. sculpta), intermediate (Surirella ovalis and Mastogloia elliptica) and low (Epithemia adnata) salinities. At $12.3 \mathrm{cal}$. ka $\mathrm{BP}$, the assemblage was more homogeneous as regard species tolerance to salinity and specific optima were in average lower than in the previous assemblage. The dominance of $T$. faurii was shared with the $\left.183 \mu \mathrm{S} . \mathrm{cm}^{-1}\right)$. The other subdominant taxa were poorly represented (<2\%), like the freshwater species Amphora pediculus and Nitzschia epiphytica, and the salinity tolerant Rhopalodia gibberula.

\section{4- Discussion}

\subsection{Taxonomy of T. faurii}

187 The original description of T. faurii by Gasse (1975, initially assigned to the genus Coscinodiscus) was 188 restrictive with regard to morphological characteristics (diam. 40-55 $\mu \mathrm{m}, 9-10$ areolae and 7 marginal 189 fultoportulae in $10 \mu \mathrm{m}$ ) and did not include information about central fultoportulae and rimoportulae. As Hasle 190 (1978) created the current combination, the range of variations of the species was extended after 191 examination of material from East Africa (32 specimens) in LM and SEM: diam. 18-43 $\mu \mathrm{m}, 13-18$ areolae and 192 6-9 marginal fultoportulae in $10 \mu \mathrm{m}$. The modern form found in lake Langano and the fossil one from lake 193 Abiyata was closer to this second definition of the taxon (Fig. 4). However, the number of central 
194 fultoportulae and rimoportulae was more variable in the material examined in this study. According to Hasle 195 (1978), there were three central fultoportulae located " $120^{\circ}$ apart", and 3-4 rimoportulae. A description of the 196 species was made by Genkal et al. (2001) from the slightly alkaline Lake Rukwa (Tanzania, pH 8.5, 3-4 mEq $\left.197 \mathrm{HCO}_{3}{ }^{-} / \mathrm{CO}_{3}{ }^{2-}\right)$. The occurrence of $T$. faurii was also reported outside intertropical Africa: in the Tisza River in 198 Hungary (Kiss et al., 1984), at the mouth of the Danube in the Black Sea (Genkal et al., 2009) and in little 199 mineralized Karelian lakes (Genkal and Chekryzheva, 2011). Kiss et al. (1984) and Genkal et al. (2001) 200 observed a variable number of central fultoportulae, from 3 to more than 6 , arranged in triangles or squares, 201 some of them clustered in pairs. This is in better agreement with our observations.

202 Pienaar and Pieterse (1990) described a new species from the Vaals River (South Africa) closely related to 203 T. faurii. They called it $T$. duostra because on most valves, central fultoportulae were clustered mostly in 204 groups of two or three, and rarely isolated. As the clustering of central fultoportulae was also often observed 205 (even in groups of three) in T. faurii from the Ziway-Shala system, this aspect may not be fully appropriate to 206 distinguish between the two species. Recently, Kiss et al. (2012) reported the presence of T. duostra in lakes 207 and rivers of Hungary. The arrangement of central fultoportulae on the valve face was very similar to the one 208 observed on large specimens of $T$. faurii from lake Langano. More research would be needed to 209 unambiguously separate the two species and define their geographic distribution, or alternatively to merge 210 them in a single taxonomic entity.

211 Sexual reproduction of T. faurii was typical of centric diatoms (Round et al., 1990). It occurred within a single 212 clone (homothallic) with a synchronic production of male and female gametes by two types of parental cells. 213 The observed association of gametes suggests that fertilization took place although autogamy could not be 214 excluded (Mills and Kaczmarska, 2006; Chepurnov et al., 2006).

\section{$215 \quad 4.2$ Autecology and ecotypes}

216 The test of salinity tolerance informed directly about the range of salinity at which the local strain could 217 develop. It demonstrated the very low ability of the strain to adapt to higher salinity levels: an increase from 2181750 to $2000 \mu \mathrm{S} . \mathrm{cm}^{-1}$ was enough to completely block cell growth until the end of the test. The time of the 219 experiment was extended to 15 days in order to let cells accommodate to salinity change (Roubeix et al., 220 2008). In a preliminary test, similar results had been obtained by adding $\mathrm{Na}_{2} \mathrm{CO}_{3}$ salt into the growth 221 medium. However, the method of evaporation/dilution to prepare test conditions was preferred, because it mimicked natural processes (salt concentrations by solar heating and dilution by rainfall) and because in this way, the correlation between $\mathrm{pH}$ and salinity was similar in the experimental flasks (Fig. 7) and in the lakes of the Ehtiopian rift (Kebede et al., 1994). Salt addition to lake water resulted in a lower pH, which was not 
representative of the natural salinity gradient formed by the chain of lakes along the rift. Water composition in salts might have been slightly altered by carbonate precipitation during the evaporation process, but it did not affect diatom growth, after dilution with deionised water for T. faurii, and directly in the concentrated water for Anomoeoneis sphaerophora (Fig. 7).

The high sensitivity of $T$. faurii to salinity was unexpected because it was described as a species living in

230 hyper-alkaline waters and often associated to the halophilous $A$. sphaerophora (Gasse 1986). Both species

231 were present in lake Langano, but the experiment showed that their co-occurrence was not possible at high

232 salinities. The salinity optimum of T. faurii derived from the African data set (Gasse et al., 1995) was

233 estimated to be approximately $9,000 \mu \mathrm{S} . \mathrm{cm}^{-1}$. Although the species occurred in lake Langano and in the

234 neighbour freshwater lake Ziway $\left(300\right.$ to $\left.600 \mu \mathrm{S} . \mathrm{cm}^{-1}\right)$, this value was high because T. faurii was also found

235 with high relative abundance $(\approx 30 \%)$ in saline swamps from Niger (Guidimouni) where the conductivity was

$23613,500 \mu \mathrm{S} . \mathrm{cm}^{-1}$. The apparent inconsistency between experimental and empirical results suggests that the

237 taxonomic entity might include several distinct species, having different ecological preferences. An a

238 posteriori detailed examination and morphometric study of the populations from Niger at LM showed that the

239 individuals had a diameter lower than $30 \mu \mathrm{m}$ and that the density of areolae and marginal fultoportulae was

240 slightly higher than in the Ziway-Shala system, although in the range of the species definition (Fig. 4).

241 Genetical studies have revealed that a diatom species presenting a wide ecological range in the environment 242 could be a complex of stenotopic, cryptic or pseudocryptic species, even in the same hydrosystem (e.g.,

243 Vanelslander et al., 2009; Poulícková et al., 2010). The African database may have included two ecotypes of

244 T. faurii, a freshwater one from the Ziway-Shala system and a salinity tolerant one from Niger. It is necessary

245 to distinguish them in order to gain precision in paleolimnological reconstructions, especially when the 246 species is dominant in a fossil assemblage.

247 Several arguments lead to consider that the species present in the sediments of lake Abiyata was sensitive 248 to salinity, as the clone isolated from lake Langano. First, lakes Abiyata and Langano are very close to each 249 other and are part of the same lake system which formed a unique lake during the humid Early Holocene 250 (Gillespie et al., 1983). Thus it is likely that the fossil diatoms of lake Abiyata belong to the same species as 251 the modern populations found recently in lake Langano. Second, the fossil and modern populations were 252 very similar morphologically and differed slightly from the salinity tolerant populations from Niger (Fig. 4) 253 which may form an allopatric ecotype, given the geographical distance from the Ziway-Shala system. 254 However, their could be sympatric ecotypes with different affinities for salinity, dispersed among the lakes of 255 the Ziway-Shala system, as observed along the salinity gradient of the Scheldt estuary for Navicula phyllepta 
(Vanelslander et al., 2009). This is unlikely because data from the modern training set (Gasse et al., 1995) and from two short cores from lakes Langano and Abiyata (Legesse et al., 2002, Gasse, unpublished data) showed that the repartition of $T$. faurii in the basin was restricted to low salinity lakes, especially lake Langano and to a much lower extent, to the freshwater lake Ziway (conductivity lower than $600 \mu \mathrm{S} . \mathrm{cm}^{-1}$ ).

260 The lower abundance of $T$. faurii in lake Ziway than in lake Langano, though conductivity appeared more 261 suitable for the species in the first lake, may be explained by other limiting abiotic factors (Juggins, 2013) or 262 by a higher competition with strictly freshwater species.

263 The very rare specimens reported from salted lake Abiyata or lake Shala (both having potentially 264 conductivities over $20,000 \mu \mathrm{S} . \mathrm{cm}^{-1}$, Kebede et al., 1994) may be due either to transport of frustules from lake 265 Langano via the Bulbula River (Abiyata) or to a taxonomic overlap between small cells of $T$. faurii and large cells of $T$. rudolfii, a species often abundant in these salted lakes and very similar to T. faurii (Hasle, 1978; Roubeix and Chalié, unpublished). Finally, a last argument in favor of a freshwater ecotype in the sediments is the association of $T$. faurii with typically freshwater taxa, especially Pseudostaurosira brevistriata. This species was co-dominant with T. faurii in the sediments of lake Abiyata at 12.3 cal ka BP (Fig. 9). It was also present with T. faurii at $6 \mathrm{ka} \mathrm{BP,}$ in lake Awassa, about $40 \mathrm{~km}$ South of lake Shala (Telford et al., 1999).

272 The Holocene history of the Ziway-Shala system is marked by a prolonged period of low conductivity 273 between 11 and 5.5 cal ka BP (Chalié and Gasse, 2002; Fig. 8), corresponding to the African Humid period (deMenocal, 2000). The four modern lakes formed at this time a unified freshwater lake (Gillespie et al., 1983). At 5.5 cal ka BP, the large increase in conductivity resulted from a drier climate and the separation of lake Abiyata which became a terminal lake, as it is still today. The amplitude of the dry event which preceded the 6 ka-long humid period in the basin was questioned by this study on T. faurii. Indeed, it appeared here that lake conductivity at 13.5 and 12.5 cal ka BP could not be as high as at 5.5 cal ka BP, after the midHolocene major climatic transition, as previously reconstructed (Chalié and Gasse, 2002).

The determination of a specific ecological optimum from ecophysiological tests on a natural strain can give more precision and local relevance to transfer functions. This approach, at the thematic interface between hydrobiology and paleolimnology, may be particularly suitable for paleoenvironmental reconstructions when empirical data on a species are too sparse (Saros, 2009).

In this study of $T$. faurii, the derivation of a salinity optimum from experimental growth rates instead of abundances in various lakes, and the incorporation of this optimum into the African transfer function, resulted in low inferred conductivities when the species was abundant in the Ziway-Shala lake system. This was 
opposite to previous reconstructions and inconsistent with dry climatic spells at 12.5 and $13.5 \mathrm{cal} \mathrm{ka} \mathrm{BP}$

288 (Chalié and Gasse, 2002). The revisited conductivity curve showed near the Pleistocene-Holocene transition, 289 only one episode of slightly higher values between 12 and $11 \mathrm{cal}$ ka BP, when T. faurii was not present. This 290 event coincided in time with a lowstand of the Ziway-Shala lake system reported by Gillespie et al. (1983) 291 and may correspond to a drier climate than after 11 cal ka BP.

292 Before 12 cal ka BP, diatom-inferred conductivity was as low as during the Early Holocene $\left(\approx 400 \mu \mathrm{S} . \mathrm{cm}^{-1}\right)$. 293 However, the transfer function including the experimental optimum of $T$. faurii may have underestimated lake 294 conductivity. Indeed, T. faurii is currently dominant in the plankton of lake Langano (Fig. 2) although salinity 295 in the lake is at the upper limit of the experimental tolerance range of the species (Fig. 7). A simple analogy 296 with modern conditions in the Ziway-Shala basin and neighbour lakes would lead to the conclusion that lake 297 conductivity at $12.2,12.5$ and 13.5 cal ka BP was rather similar to current conductivity in lake Langano (1700 $298 \mu \mathrm{S} . \mathrm{cm}^{-1}$ ) which has also notably the species $R$. gibberula and $P$. brevistriata in common with the sediment 299 samples (Fig. 2 and 9). Such a conductivity level would be enough to invoke a lower lake level and a drier 300 climate compared to the period 11-6 cal ka BP.

301 The weighted average method was used to determine a specific optimum from experimental results for 302 consistency with the method used in the transfer function from empiric data. However, this method is efficient 303 when the distribution of the data is unimodal and approximately symmetric. The experimental results 304 revealed rather a threshold effect with low variations below $2000 \mu \mathrm{S} . \mathrm{cm}^{-1}$. As the diatom grew well at 1750 $305 \mu \mathrm{S} . \mathrm{cm}^{-1}$ in culture (for maintenance) and in lake Langano (months of July and September as suggested by its 306 dominance in the community), a maximum conductivity optimum of $1750 \mu \mathrm{S} . \mathrm{cm}^{-1}$ should be considered to account for experimental uncertainty. This maximum defines the upper level to which the previously

308 reconstructed peaks of conductivity should be reduced at the Pleistocene-Holocene transition (Fig. 8). At this 309 maximum, the Younger Dryas chronozone (Bard and Kromer, 2003) remains less dry than present-day 310 (Legesse et al., 2002; Gasse, unpublished), but it shows a major reversal pattern, as conductivity re311 increased to about the same level at 12.5 than at 13.5 cal ka BP.

312 Drops in lake level have been recorded in many sites of tropical Africa North of $8^{\circ} S$ during the Younger Dryas 313 (e.g. Gasse, 2000; Shanahan et al., 2006; Marshall et al., 2011). This was attributed to an intensification of 314 dry northern trade winds and a southward shift of the ITCZ (Garcin et al., 2007). This aridification may have 315 caused in the Ziway-Shala system a decrease in lake level and a moderate increase in conductivity. This environmental change towards an intermediate state between Early Holocene highstand and current 317 lowstand of the lakes, probably benefited to $T$. faurii which became the dominant diatom species. The 
analysis of fossil diatom assemblages revealed a change between 12.5 and 12.3 cal ka BP. Indeed at 12.5

319 cal ka BP, all diatoms associated with $T$. faurii were benthic and the large distribution of conductivity optima

320 (Fig. 9) suggests a lower lake level and/or a higher seasonal to interannual climate variability, both

321 enhancing the range of short-term variations of water salinity (Roubeix and Chalié, submitted).

322 The reconsideration of $T$. faurii as a possibly freshwater species may lead to revisit paleoenvironmental

323 reconstructions from other sedimentary deposits in intertropical Africa where the species was present at high

324 abundance. For example, this could solve the apparent inconsistency of a high inferred conductivity in lake

325 Awassa contemporaneous with a highstand of the neighbour Ziway-Shala system between 5 and $4{ }^{14} \mathrm{C}$ ka

326 BP, without necessarily invoking salted hydrothermal inflows (Telford et al., 1999). In the same way, the co-

327 occurrence of $T$. faurii with typical freshwater species (e.g. Aulacoseira granulata) in sediment samples from

328 lake Rukwa (Tanzania) may not require the assumption of a strong seasonality of climate and water salinity

329 (Barker et al., 2002).

\section{Acknowledgments}

332 This study was performed in the frame of the French ANR (Agence Nationale pour la Recherche) Project

333 ELPASO 'EI Niño: Lessons from the PAst, using Simulations and Observations' ( $N^{\circ} 2010$ BLANC 608 01),

334 including a post-doctoral contract (V.R.). We thank Dr Dagnachew Legesse (Dept of Earth Science, Addis

335 Abeba University, and IAEA Vienna) for supporting our work, and for facilitating scientific collaborations in

336 Ethiopia, and Dr Seyoum Mengistou (Dept of Biology, Addis Abeba University) for help with field

337 authorisations in Ethiopia, and for organising our joint scientific plans. Getachew Beneberu and Gebeyehu

338 Demeke provided highly helpful field assistance on lakes Langano and Ziway. Thanks are due to M.

339 Decobert for organising the field expedition with support of the SETEL-CEREGE (Service-Etudes-Terrain-

340 Equipement-Logistique). We are grateful to the 'Service de Coopération et d'Action Culturelle' of the French

341 Embassy in Addis Abeba, for a very constructive logistic support.

\section{References}

344 Bard, E., Kromer, B., 2003. Absolute and radiocarbon chronologies of the Younger Dryas cold period, in:

345 Widemann, F., Taborin, Y. (Eds.), Geophysical and archaeological chronologies for the Upper Palaeolithic.

346 Edipulgia, Bari, pp. 375-379. 
Barker, P., Telford, R., Gasse, F., Thevenon, F., 2002. Late Pleistocene and Holocene palaeohydrology of 348 Lake Rukwa, Tanzania, inferred from diatom analysis. Palaeogeogr Palaeoclimatol Palaeoecol 187, 295349305.

350 Birks, J.B., Heiri, O., Seppä, H., Bjune, A.E., 2010. Strengths and weaknesses of quantitative climate 351 reconstructions based on Late-Quaternary biological proxies. The Open Ecology Journal 3, 68-110. 352 Chalié, F., Gasse, F., 2002. Late Glacial-Holocene diatom record of water chemistry and lake level change 353 from the tropical East African Rift Lake Abiyata (Ethiopia). Palaeogeogr Palaeoclimatol Palaeoecol 187, $354 \quad 259-283$.

355 Chepurnov, V.A., Mann, D.G., von Dassow, P., Armbrust, E.V., Sabbe, K., Dasseville, R., Vyverman, W., 356 2006. Oogamous reproduction, with two-step auxosporulation, in the centric diatom Thalassiosira 357 punctigera (Bacillariophyta). J Phycol 42, 845-858.

358 Cocquyt, C., 1998. Diatoms from the Northern Basin of Lake Tanganyika. J. Cramer. 359 deMenocal, P., Ortiz, J., Guilderson, T., Adkins, J., Sarnthein, M., Baker, L., Yarusinsky, M., 2000. Abrupt 360 onset and termination of the African Humid Period: rapid climate responses to gradual insolation forcing. 361 Quaternary Sci Rev 19, 347-361.

362 Fritz, S.C., Cumming, B.F., Gasse, F., Laird, K.R., 2010. Diatoms as indicators of hydrologic and climatic 363 change in saline lakes, in: Stoermer, E., Smol, J.P. (Eds.), The Diatoms: Applications to Environmental and 364 Earth Science. Cambridge University Press, Cambridge, pp. 41-72.

365 Garcin, Y., Vincens, A., Williamson, D., Buchet, G., Guiot, J., 2007. Abrupt resumption of the African 366 Monsoon at the Younger Dryas-Holocene climatic transition. Quaternary Sci Rev 26, 690-704.

367 Gasse, F., 1975. L'Evolution des lacs de l'Afar central (Ethiopie et TFAI) du Plio-pléistocène à l'actuel: 368 reconstitution des paléomilieux lacustres à partir de l'études des diatomées. Université de Paris VI, Paris. 369 Gasse, F., 1986. East African diatoms : Taxonomy, ecological distribution. Gebruder Borntraeger 370 Verlagsbuchhandlung, J. Cramer, Berlin.

371 Gasse, F., 2000. Hydrological changes in the African tropics since the Last Glacial Maximum. Quaternary Sci $372 \operatorname{Rev} 19,189-211$.

373 Gasse, F., 2001. Paleoclimate - Hydrological changes in Africa. Science 292, 2259-2260.

374 Gasse, F., Barker, P., Gell, P.A., Fritz, S.C., Chalie, F., 1997. Diatom-inferred salinity in palaeolakes: An 375 indirect tracer of climate change. Quaternary Sci Rev 16, 547-563.

376 Gasse, F., Juggins, S., Khelifa, L.B., 1995. Diatom-Based transfer-functions for inferring past hydrochemical 377 characteristics of African lakes. Palaeogeogr Palaeocl 117, 31-54. 
Genkal, S.I., Chekryzheva, T.A., 2011. Centric Diatoms (Bacillariophyta, Centrophyceae) in Karelian Waterbodies. Inland Water Biol 4, 1-11.

380 Genkal, S.I., Makarova, I.V., Popovskaya, G.I., 2001. On morphology of Thalassiosira faurii (Gasse) Hasle 381 (Bacillariophyta). Algologia 11, 175-179.

382 Genkal, S.I., Teren'ko, L.M., Nesterova, D.A., 2009. New Data on the Centric Diatoms (Centrophyceae, 383 Bacillariophyta) of the Danube Region of the Black Sea. Hydrobiological Journal 45, 51-69.

384 Gillespie, R., Street-Perrott, F.A., Switsur, R., 1983. Post-Glacial Arid Episodes in Ethiopia Have Implications 385 for Climate Prediction. Nature 306, 680-683.

386 Guillard, R.R.L., Lorenzen, C.J., 1972. Yellow-Green Algae with Chlorophyllide C1,2. J Phycol 8, 10-14. 387 Hasle, G.R., 1978. Some Freshwater and Brackish Water Species of Diatom Genus Thalassiosira Cleve. 388 Phycologia 17, 263-292.

389 Juggins, S. (2013) Quantitative reconstructions in palaeolimnology: new paradigm or sick science? 390 Quaternary Sci Rev 64, 20-32.

391 Hustedt, 1949. Exploration du Lac National Albert: Süsswasser Diatomen aus dem Albert-National Park in 392 Belgish-Kongo. Mission H. Damas (1935-36), Brussels.

393 Kebede, E., Mariam, Z.G., Ahlgren, I., 1994. The Ethiopian Rift-Valley lakes - Chemical characteristics of a 394 salinity alkalinity series. Hydrobiologia 288, 1-12.

395 Kiss, K., Klee, R., Ector, L., Acs, E., 2012. Centric diatoms of large rivers and tributaries in Hungary: 396 morphology and biogeographic distribution. Acta Bot Croat 71, 311-363.

397 Krammer, K., Lange-Bertalot, H., 1986-89-91a,b. Süsswasserflora von Mitteleuropa: Bacillariophyceae, Vols. 398 1-4, Gustav Fischer Verlag ed, Jena.

399 Legesse, D., Ayenew, T., 2006. Effect of improper water and land resource utilization on the central Main $400 \quad$ Ethiopian Rift lakes. Quatern Int 148, 8-18.

401 Legesse, D., Gasse, F., Radakovitch, O., Vallet-Coulomb, C., Bonnefille, R., Verschuren, D., Gibert, E., 402 Barker, P., 2002. Environmental changes in a tropical lake (Lake Abiyata, Ethiopia) during recent centuries. 403 Palaeogeogr Palaeoclimatol Palaeoecol 187, 233-258.

404 Marshall, M.H., Lamb, H.F., Huws, D., Davies, S.J., Bates, R., Bloemendal, J., Boyle, J., Leng, M.J., Umer, 405 M., Bryant, C., 2011. Late Pleistocene and Holocene drought events at Lake Tana, the source of the Blue 406 Nile. Global Planet Change 78, 147-161.

407 Mills, K.E., Kaczmarska, I., 2006. Autogamic reproductive behavior and sex cell structure in Thalassiosira 408 angulata (Bacillariophyta). Bot Mar 49, 417-430. 
Pienaar, C.A., Pieterse, A.J.H., 1990. Thalassiosira duostra sp. nov. a new freshwater centric diatom from

410 the Vaal River, South Africa. Diatom Research 5, 105-111.

411 Poulickova, A., Vesela, J., Neustupa, J., Skaloud, P., 2010. Pseudocryptic Diversity versus Cosmopolitanism

412 in Diatoms: a Case Study on Navicula cryptocephala Kutz. (Bacillariophyceae) and Morphologically Similar 413 Taxa. Protist 161, 353-369.

414 Roubeix, V., Chalié, F., submitted. Extracting short-term paleoenvironmental variability from the dispersion of 415 species' ecological optima in sediment samples. J Paleolimnol.

416 Roubeix, V., Rousseau, V., Lancelot, C., 2008. Diatom succession and silicon removal from freshwater in 417 estuarine mixing zones: From experiment to modelling. Estuar Coast Shelf S 78, 14-26.

418 Round, F.E., Crawford, R.M., Mann, D.G., 1990. The Diatoms: Biology \& Morphology of the Genera.

419 Cambridge University Press.

420 Saros, J., 2009. Integrating neo- and paleolimnological approaches to refine interpretations of environmental 421 change. J Paleolimnol 41, 243-252.

422 Shanahan, T.M., Overpeck, J.T., Wheeler, C.W., Beek, J.W., Pigati, J.S., Talbot, M.R., Scholz, C.A., Peck, 423 J., King, J.W., 2006. Paleoclimatic variations in West Africa from a record of late Pleistocene and Holocene 424 lake level stands of Lake Bosumtwi, Ghana. Palaeogeogr Palaeoclimatol Palaeoecol 242, 287-302.

425 Snoeijs, P., Weckström, K., 2010. Diatoms and environmental change in large brackish-water ecosystems, 426 in: Stoermer, E., Smol, J.P. (Eds.), The Diatoms: Applications for the Environmental and Earth Sciences. 427 Cambridge University Press, Cambridge, pp. 287-308.

428 Telford, R.J., Lamb, H.F., Mohammed, M.U., 1999. Diatom-derived palaeoconductivity estimates for Lake 429 Awassa, Ethiopia: evidence for pulsed inflows of saline groundwater? J Paleolimnol 21, 409-421.

430 Vanelslander, B., Creach, V., Vanormelingen, P., Ernst, A., Chepurnov, V.A., Sahan, E., Muyzer, G., Stal, 431 L.J., Vyverman, W., Sabbe, K., 2009. Ecological differentiation between sympatric pseudocryptic species in 432 the estuarine benthic diatom Navicula Phyllepta (Bacillariophyceae). J Phycol 45, 1278-1289. 


\section{Figure 1}

435 Map of the Ziway-Shala system in Ethiopia. The stars indicate the sampling site in lake Langano and the 436 coring site in lake Abiyata.

437

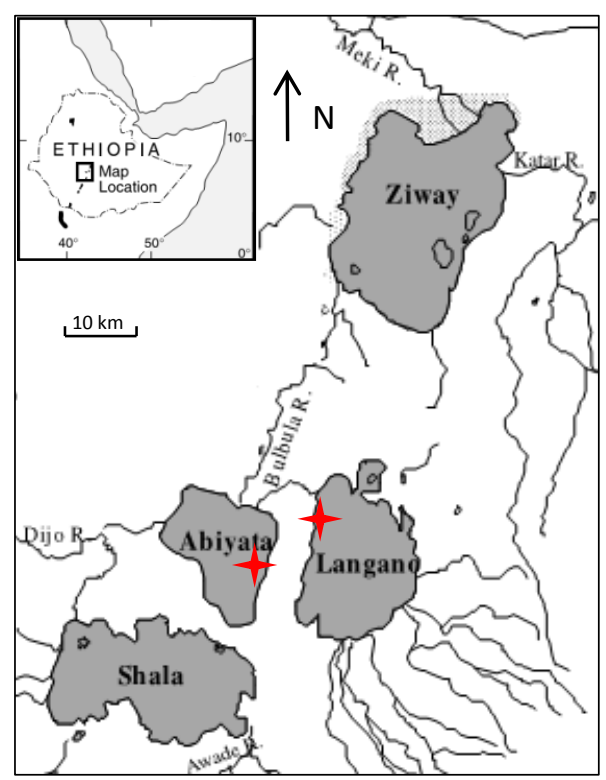




\section{Figure 2}

440 Composition of the diatom communities sampled with the sediment trap in lake Langano during the months

441 of July, August and September 2012 (only the six most abundant species are detailed).

$442 \mathrm{AULsp}=$ Aulacoseira sp., COCE $=$ Cyclotella ocellata, $\mathrm{EMUE}=$ Encyonema muelleri, FBRE=

443 Pseudostaurosira brevistriata, HVEN= Halamphora veneta, NITZsp= Nitszchia sp., NPAL= Nitzschia palea,

$444 \mathrm{RGBL}=$ Rhopalodia gibberula, SPUP = Sellaphora pupula, $\mathrm{TFAU}=$ Thalassiosira faurii.
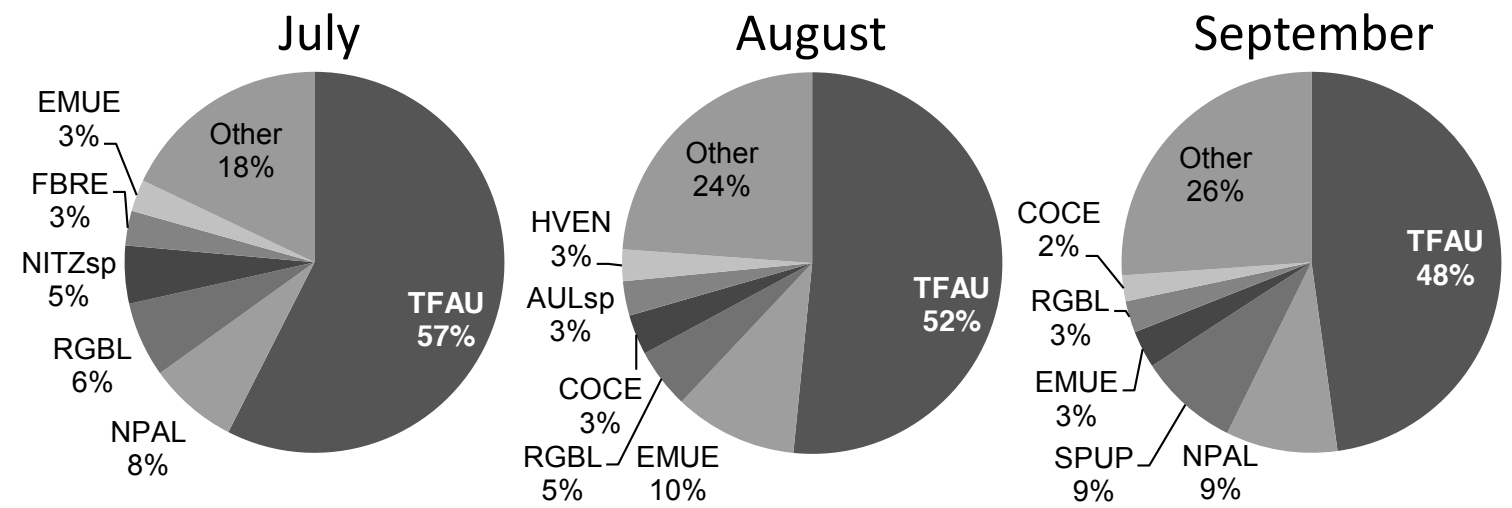

445 


\section{Figure 3}

448 Frustules of Thalassiosira faurii from lake Langano observed at scanning electronic microscope. Valve and 449 connective views $(a, b)$, external view of marginal fultoportulae and one rimoportulae $(c, d)$, internal view of 450 areolae, fultoportulae and one rimoportulae (e) and focus on one central fultoportulae (f). Scale bars $(\mu \mathrm{m})$ : $45130(a), 20(b), 10$ (c,d, same scale), 1 (e,f).
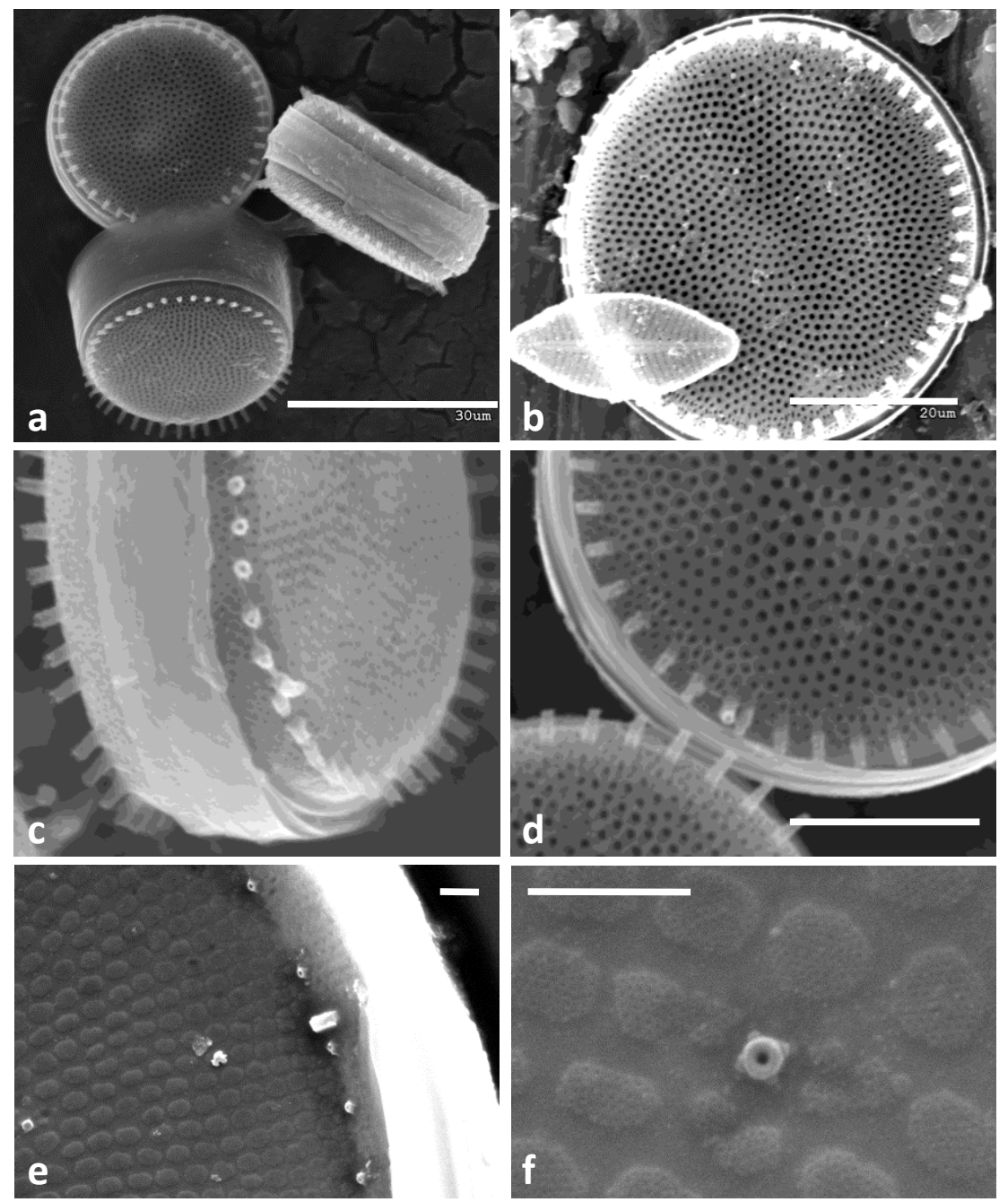
460

Figure 4

461 Biometric characteristics of populations of T. faurii, in the plankton of lake Langano (sediment trap sept 12, 462 open circles), in 12 cal. ka sediments from lake Abiyata (filled circles), in modern samples from Niger 463 (triangles) and in various samples from intertropical Africa (after Hasle, 1978; crosses)

464
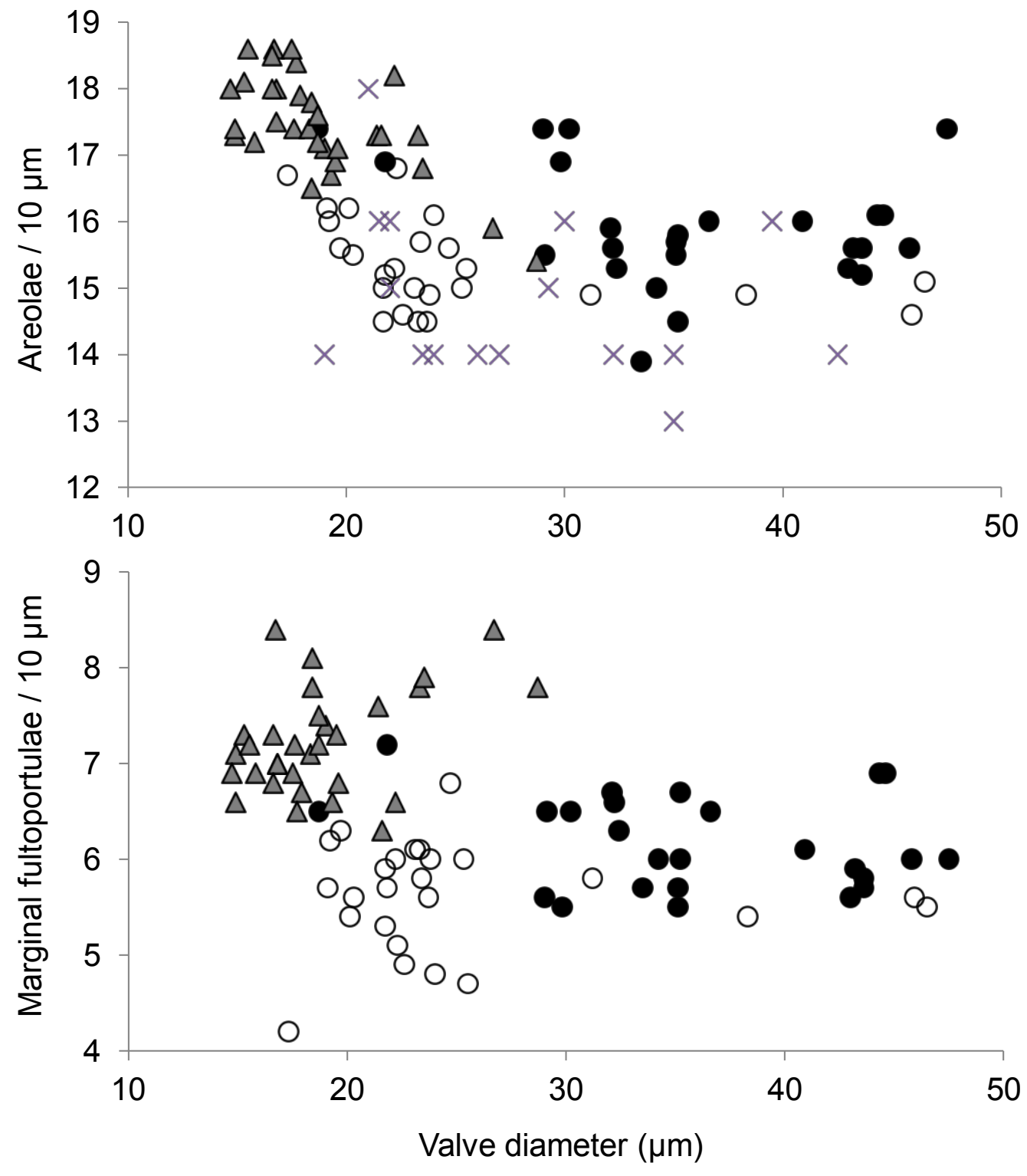
Figure 5

469 Valves of Thalassiosira faurii observed in a culture (light microscope), (a) before and after sexual

470 reproduction, (b, c) arrangement of fultoportulae (2 different valves). Scale bar $=10 \mu \mathrm{m}$.

471

472

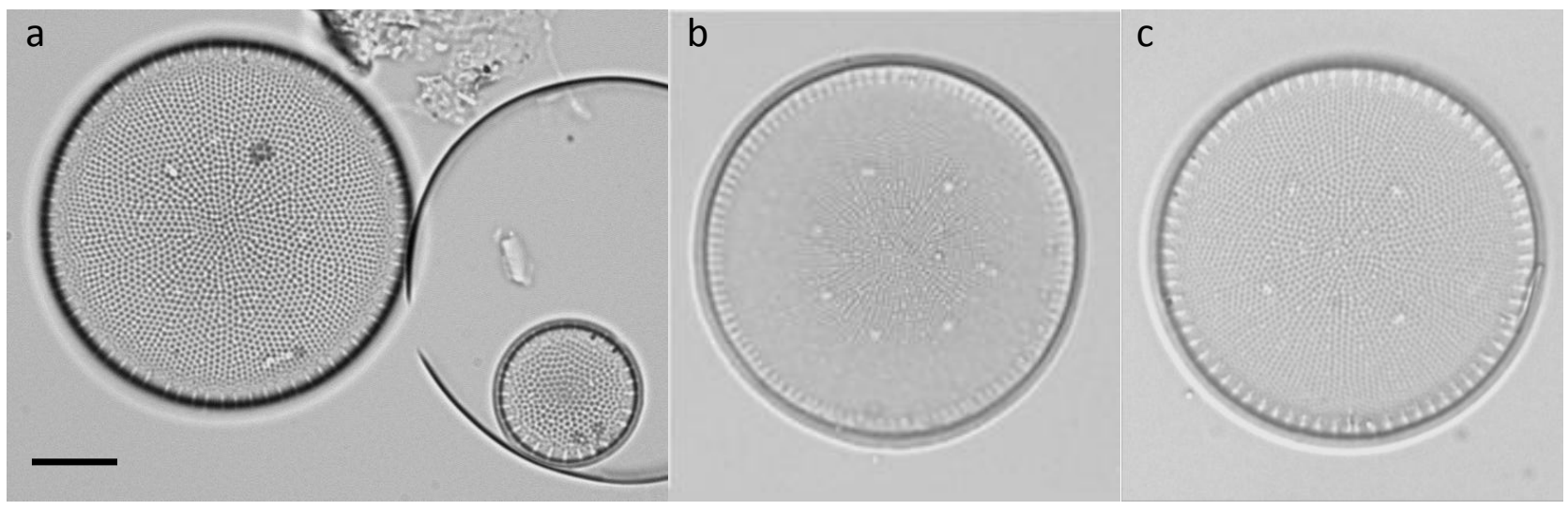

473

474

475

476

477

478

479

480

481

482

483

484

485

486

487

488 
$489 \quad$ Figure 6

490 Sexual reproduction of Thalassiosira faurii observed in a culture. Spermatogenesis (a), uniflagellate free

491 spermatozoid (b), oogonia with two attached spermatozoids (c), auxospore development between the valves

492 of an oogonia (d), formation of an initial cell from the mature auxospore (e). Scale bar $=10 \mu \mathrm{m}$.

493

494
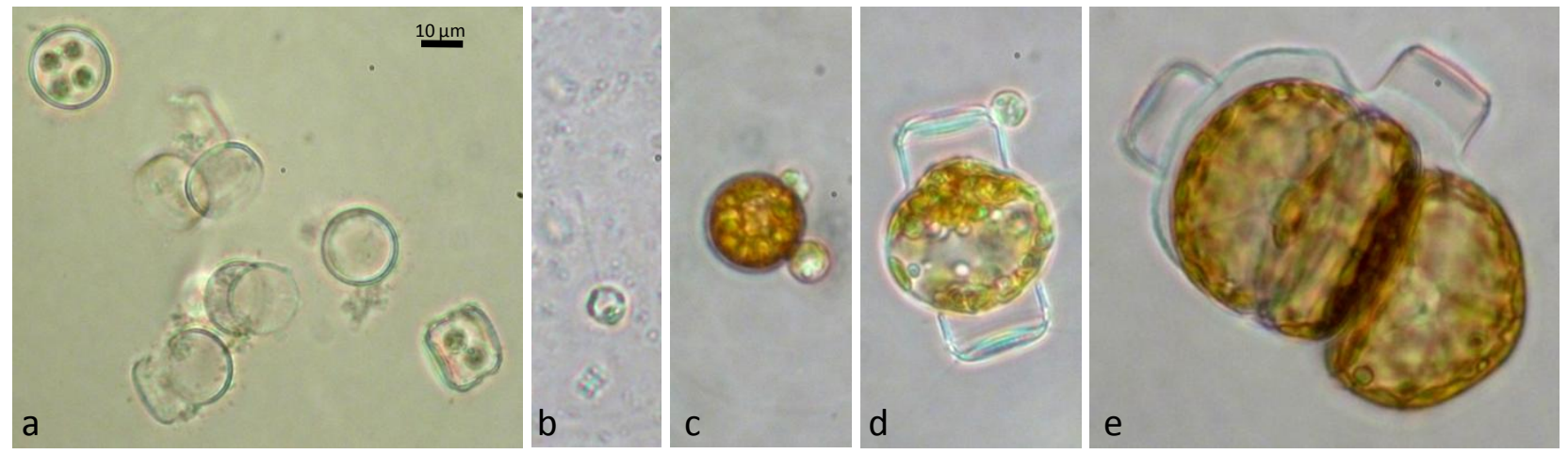
496 Growth rates of Thalassiosira faurii (black diamonds) and Anomoeoneis sphaerophora (open diamonds)

497 versus conductivity of the culture medium. The dashed line shows the variations of $\mathrm{pH}$ between cultures.

498 Vertical bars represent the standard deviations of the triplicates. A star means that the cell were still alive 499 after 15 days, whereas a cross means that they were all dead. The two triangles indicate the conductivity 500 and $\mathrm{pH}$ of lake water from which the diatoms were isolated.

501

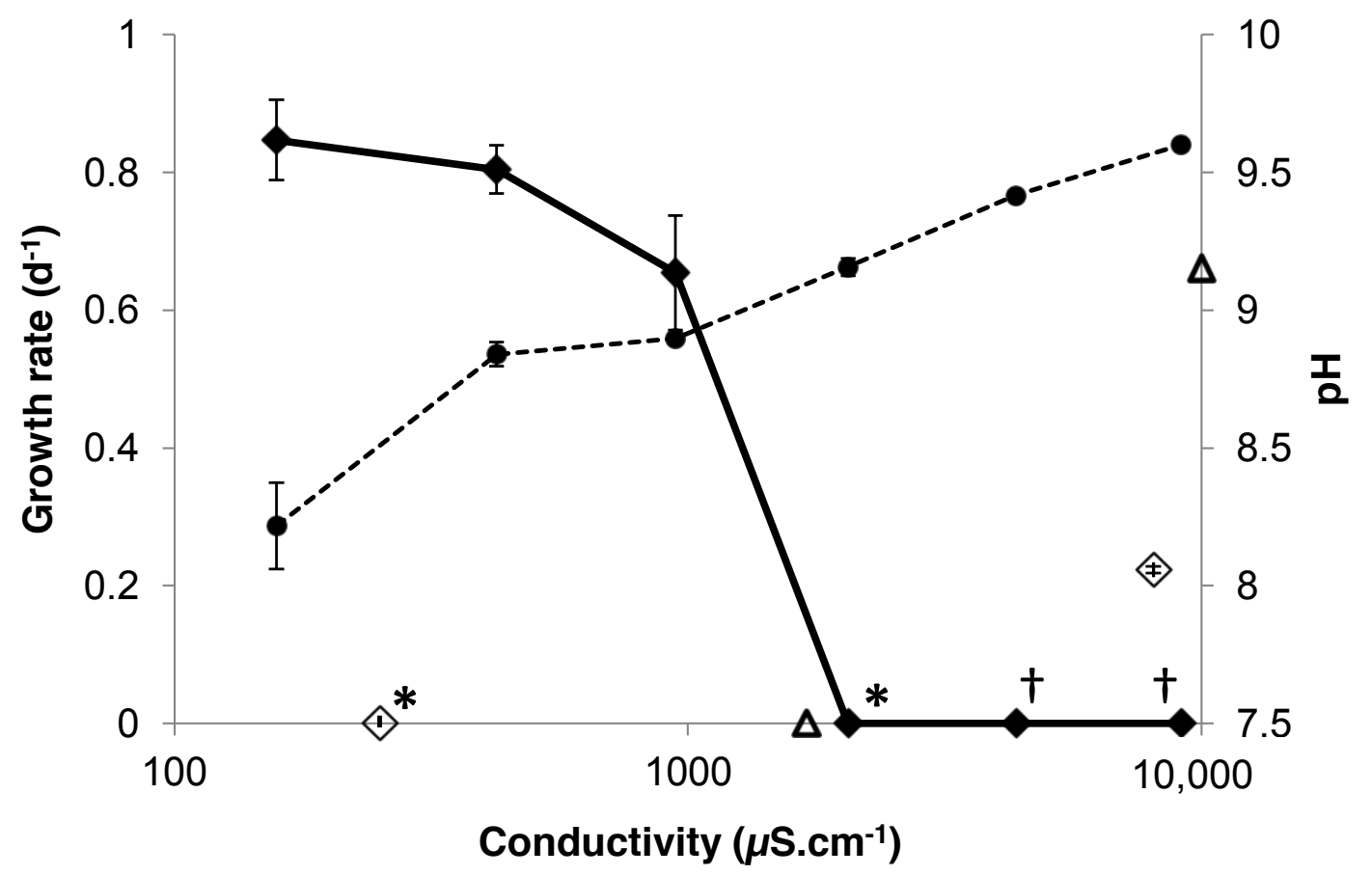


504 Diatom-inferred conductivity from a sediment core extracted from lake Abiyata (Chalié and Gasse, 2002), using the empirical conductivity optimum of Thalassiosira faurii for the last 13.5 cal. ka BP (a). Focus on the

506 period 13.5-10 cal. ka BP (b): empirical conductivity as in (a) (squares, black line), reconstructed conductivity 507 using the new experimentally-derived optimum (open circles, black line), and with the maximal possible value 508 of the optimum (open circles, dashed line, see discussion). Relative abundance of Thalassiosira faurii in core 509 samples (c).

510

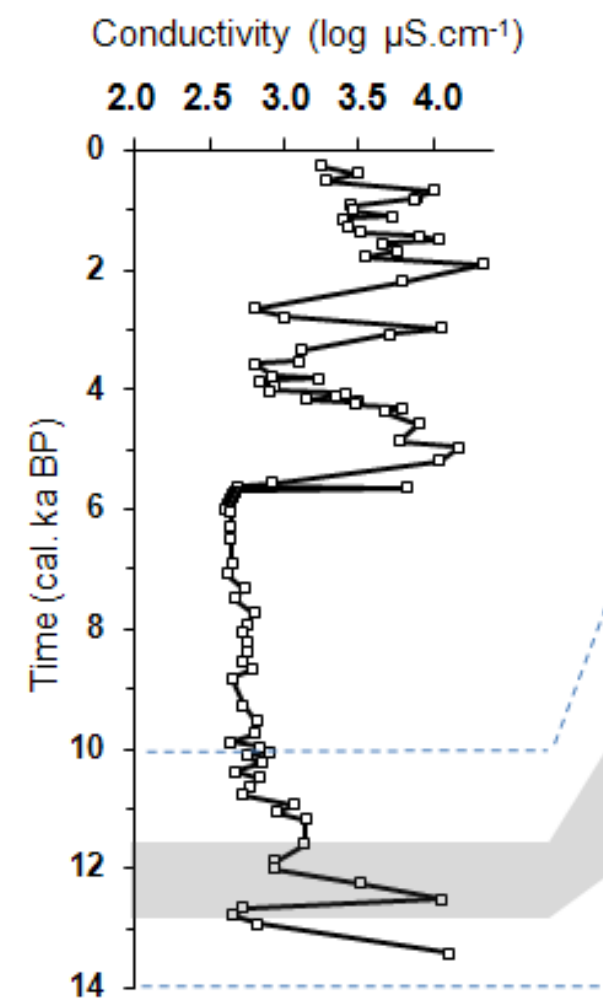

a
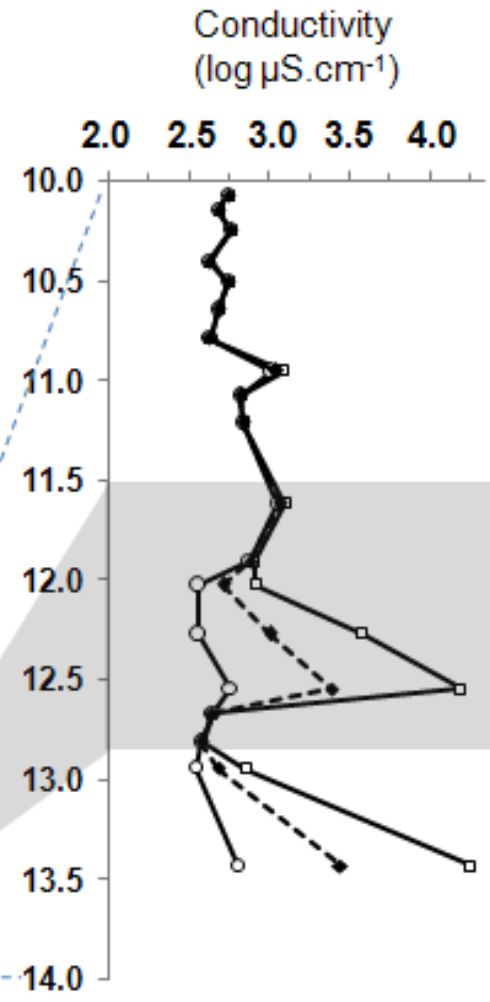

$\begin{array}{lllll}2.0 & 2.5 & 3.0 & 3.5 & 4.0\end{array}$

b
Relative abundance of T.faurii (\%) 


\section{$513 \quad$ Figure 9}

514 Distribution of species conductivity optima in the fossil diatom assemblage from two consecutive sediment

515 samples from lake Abiyata at 12.5 and 12.3 cal ka BP, when the relative abundance of Thalassiosira faurii

516 was 72 and $51 \%$ respectively. The line represents the relative abundance of each class in the assemblage.

517 T. faurii is not taken into account, but its empirical and experimental conductivity optima are indicated by

518 triangles. $\mathrm{APED}=$ Amphora pediculus, $\mathrm{EADN}=$ Epithemia adnata, $\mathrm{FBRE}=$ Pseudostaurosira brevistriata,

519 MELL= Mastogloia elliptica, NEPI= Nitzschia epiphytica, RGBL= Rhopalodia gibberula, SOVI= Surirella 520 ovalis.

\section{3 cal kyr BP}

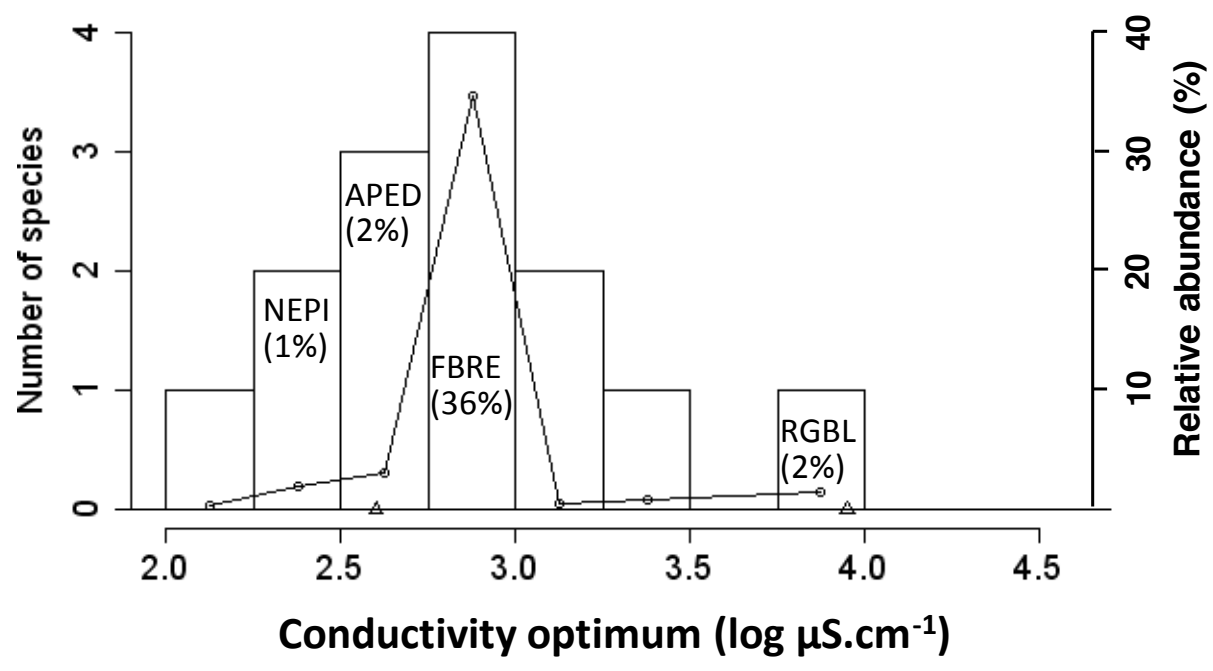

\section{5 cal kyr BP}

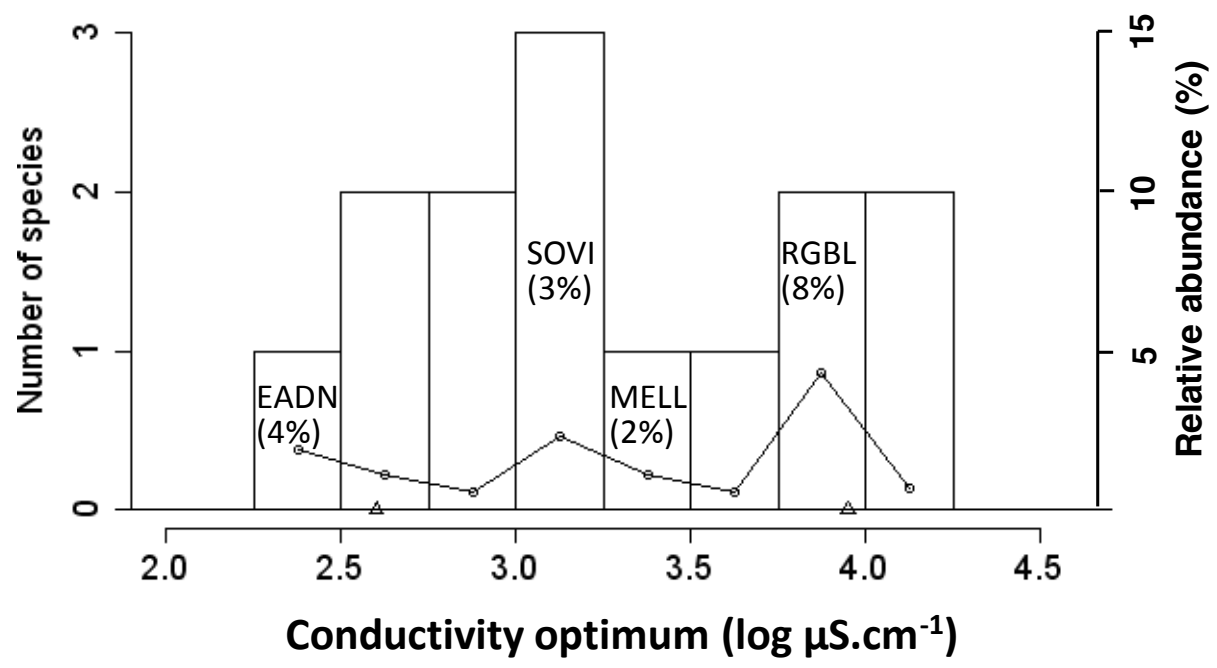

